\title{
MEKANISME PRINSIP-PRINSIP SYARIAH DALAM OPERASIONAL BANK
} SYARIAH

\author{
Wafda Vivid Izziyana \\ Universitas Muhammadiyah Metro \\ wafda.vivid@yahoo.com
}

\begin{abstract}
Abstrak
$\int^{\mathrm{k}}$ konomi Islam di Indonesia, khususnya di industri perbankan, mengalami pertumbuhan pesat. Pada tahap awal era perbankan syariah, hanya ada satu bank umum syariah yang beroperasi dan hanya terbatas oleh kantor yang memberikan layanan perbankan syariah. Fenomena tentang ekonomi Islam memiliki bentuk perkembangan yang resmi dan bahkan modernisasi fiqh muamalah Maliyah. Umumnya, fatwa merupakan penjelasan-penjelasan hukum-hukum yang terdiri dari pedoman untuk lembaga keuangan. Penafsiran seperti itu sangat dibutuhkan oleh praktisi ekonomi Islam. Dalam hal ini, DSN akan memberikan bimbingan dan penjelasan kepada orang-orang pada norma ekonomi Islam. Dalam studi ilmu fiqh klasik, fatwa hanya mengikat bagi mereka yang meminta fatwa dan mengeluarkan fatwa. Namun, konsep fatwa ini kemudian diganti dan diperbarui, saat ini fatwa DSN pada ekonomi Islam tidak hanya mengikat bagi praktisi ekonomi dan DSN personil Islam tetapi juga umat Islam di Indonesia yang bertransaksi dengan menggunakan Bank Syariah. Selain itu, fatwa ini telah disahkan oleh Peraturan Bank Indonesia.
\end{abstract}

Kata Kunci: Prinsip, Bank Syariah

\begin{abstract}
$S$ haria Economic in Indonesia, especially in banking industry, experiencing rapid growth. At the earliest of the banking industry, there was only one general sharia which based on bank operating and only limited banking that provide services syariah. The Islamic economics having the form of the development such as modernization maliyah. Basically fatwa have function to give proofs of the laws consisting of guidelines for financial institutions. Interpretation about Islamic law were really needed by practitioner of the islamic economy. In this case, DSN will provides guidance and explanation to people in a norm of islamic economy. In the study of the science fiqh classical, fatwa shall only be bound for those who will ask and bring fatwa. Furthermore, the concept of fatwa were then replaced and renewed, now DSN fatwa about the islamic economy not only binding on the economic practitioner and DSN Islamic personnel but also muslims in indonesia who transact by using Sharia Banking. Moreover, this fatwa already have legitimation by the regulation of Bank Indonesia.
\end{abstract}

Keywords: The Principle, Sharia Banking

\section{PENDAHULUAN}

History dalam perbankan Islam di dunia telah tercatat sejak awal 1950-an sebagai pembahasan tentang riba dan bunga bank yang dimulai tumbuh berkembang. Setelah pembahasan tersebut, operasi bank non-bungan disusulkan. Bank Islam pertama kalli didirikan di Mesir pada tahun 1963, yang pada awalnya tidak menerapkan operasi berbasis bunga. Mit Ghamr Bank Tabungan 
menyediakan layanan dasar perbankan, seperti tabungan, pinjaman, ekuitas investasi langsung, dan pelayanan sosial. Pengenalan sistem perbankan Islam seperti itu mudah diterima oleh masyarakat setempat, yang dibuktikan dengan penigkatan jumlah nasabah bank dan jumlah peningkatan uang yang didepositokan di bank. ${ }^{1}$

Akan tetapi, kesuksesan Mit Ghamr tersebut tidak berlangsung panjang. Setelah berjalan selama kurang lebih empat tahun, sebagai akibat dari permasalahan politik, pengoperasian Mit Ghamr diambil alih oleh Bank Nasional Mesir dan Bank Sentral Mesir pada tahun 1967. Meskipun Bank Tabungan Mit Ghamr ditutup secara paksa dan terpaksa menghentikan operasinya sebelum mencapai kematangan bisnis, pendirian bank itu tetap menunjukkan bahwa sistem perbankan syariah adalah sistem perbankan yang sesuai untuk masyarakat muslim, dan hal itu tidak bisa untuk disangkal. Apresiasi yang tinggi dari masyarakat terhadap Bank tabungan Mit Ghamr juga menunjukkan bahwa bank-bank Islam dapat diterima secara luas oleh semua orang. ${ }^{2}$

Peristiwa bersejarah antar kedua negara tersebut, yakni pengembangan perbankan syariahmerupakan pembentukan Islamic Development Bank (IDB). Pembentukan IDB pertama kali dimulai pada tahun 1970 selama KTT Organisasi Konferensi Islam (OKI) di Karachi, Pakistan. Pada saat itu, Mesir mengusulkan pembentukan sebuah Bank Islam, dan ususlan tersebut secara pasti di setujui oleh 18 anggota OKI. Sebagai tindak lanjut, usulan itu dibahas lebi lanjut dalam KTT OKI yang diselenggarakan di Benghazi Libya. KTTmemutuskan bahwa OKI harus memiliki badan khusus untuk menangani masalah keuangan dan ekonomi. Setelah finalisasi rencana pendirian bank, IDB secara resmi didirikan pada bulan Oktober 1975. Selanjutnya, ia menyatakan bahwa semua negara anggota OKI secara otomatis menjadi anggota IDB. Pembentukan IDB telah menginspirasi dan memotivasi negara-negara muslim lain untuk membangun lembaga keuangan Islam mereka sendiri. Karena negara-negara muslim lainnya sangat antusias untuk mendrikan bank-bank Islam mereka sendiri, IDB menyiapkan panitia khusus untuk mengatur pedoman untuk persiapan., pembentukan, peraturan, dan pengawasan bank syariah. Pedoman ini kemudian diadopsi secara luas sebagai petunjuk bagi semua lembaga keuangan Islam di dunia. ${ }^{3}$

Perkembangan industri perbankan di Indonesia dapat dilihat melalui perkembangan perekonomian Indonesia, ketika perdagangan domestik dan internasional telah mempengaruhi perkembangan ekonomi dan perbankan Indonesia. Hal ini akan memberikan arah yang lebih jelas tentang perkembangan syariah didasarkan pada perkembangan ekonomi makro Indonesia. ${ }^{4}$

Histori perkembangan Indonesia sangat dipengaruhi oleh sistem perbankan Belanda, karena Belanda mewarisi sistem perbankan untuk negara jajahannya. Pada tahun 1953, awal terbentuknya perbankan dilakukan di Indonesia, dengan didirikannya bank sentrak Indonesia yang disebut Bank Indonesia (BI). Yang mana BI merupakan bank sentral yang mengeluarkan peraturan tentang pengelolaan perbankan di negara itu. Pembentukan BI adalah hasil dari nasionalisasi Bank De Javasche, yang didirikan oleh kolonial Belanda di Batavia (Jakarta) pada tanggal 24 Januari 1828. Kemudian, bank-bank Belanda lainnya juga dinasionalisasi. Bank Central mengelola seluruh transaksi keuangan bank yang beroperasi di Indonesia.

Di Indonesia, upaya untuk merintis perbankan syariah dimulai padaawal tahun 1980-an. Ada banyak diskusi tentang bank syariah yang berfungsi sebagai pilar ekonomi Islam. Sebagai tahap percobaan, gagasan perbankan Islam dipraktekkan dalam skala yang relatif terbatas. Bait At-Tamwil Salman ITB didirikan di Bandung dan Koperasi Ridho Gusti (Ridho Gusti Koperasi) muncul di

$1 \quad$ Sutan Remy Sjahdeini, 1993, Kebebasan Berkontrak dan Perlindungan yang setimbang bagi para Pihak dalam Perjanjian Kredit Bank di Indonesia, Jakarta, Institut Bankir Indonesia.

2 Fathurahman Djamil, 2002, Urgensi Undang-Undang Perbankan Syariah di Indonesia, Jurnal Hukum Bisnis, hlm. 39

3 Gemala Dewi, 2006, Aspek-Aspek Hukum Dalam Perbankan Dan Peransurasian Syariah Di Indonesia, Jakarta, Prenada Media, Hlm. 54.

4 Muhammad Nadratuzzaman, 2013, Islamic Finance Product In Indonesia And Malaysia, Jakarta, Gramedia, hlm. 19. 
Jakarta. Sebuah upaya rintisan yang lebih istimewa dari pendirian bank Islam di Indonesia dimulai padatahun 1990. Pada saat itu, Majelis Ulama Indonesia (MUI) melakukan lokakarya tetang bunga bank dan perbankan di Cisarua, Bogor Jawa Barat. Hasil lokakarya tersebut kemudian dibahas dalam konferensi keempat nasional MUI yang diselenggarakan di Jakarta pada bulan Agustus 1990. Konferensi ini mengamanatkan pembentukan kelompok kerja pendirian bank Islam. kelompok kerja ini disebut sebagai Tim Perbankan MUI, yang diberi mandat untuk mendekati dan berkonsultasi dengan semua pihak yang terkait. ${ }^{5}$

Pembentukan Bank Islam pertama sepenuhnya dipelopori oleh MUI dan pemerintah Indonesia, dan didukung oleh Asosiasi Cendekiawan Muslim Indonesia (ICMI) dan beberapa pengusaha muslim. Karena modal uang yang dibutuhkan untuk mendirikan bank Islam pertama dianggap memadai, PT Bank Muamalat Indonesia (BMI) didirikan pada tanggal 1 November 1991. Sejak 1 Mei 1992, BMI resmi beroperasi dngan modal awal sebesar Rp 106 Miliar. Selama kurang lebih enam tahun, BMI merupakan satu-satunya bank yang beroperasi pada sistem berbasis non bunga, namun ada sekitar 78 BPR Syariah (BPRS) yang beroperasi pada saat itu. Dua tahun sejak resmi berdirinya pada tanggal 27 Oktober 1994, BMI berhasil mencapai status bank devisa. Hal ini memperkuat posisi bank sebagai bank syariah terkemuka pertama di Indonesia.

Secara resmi, keberadaan bank syariah diakui di Indonesia, pengakuan tersebut telah diberikan sejak berdirinya BMI. Untuk bisa melihat dan membandingkan perkembangan usaha perbankan syariah maka perlu dianalisis terkait peran pengawas syariah, peran dan posisi fatwa untuk pengembangan perbankan syariah serta produk perbankan syariah.

\section{PEMBAHASAN}

\section{Peran Pengawas Syariah}

Ekonomi Islam di Indonesia, khususnya di industri perbankan, mengalami pertumbuhan pesat. Pada tahap awal era perbankan syariah, hanya ada satu bank umum syariah yang beroperasi dan hanya terbatas oleh kantor yang memberikan layanan perbankan syariah. ${ }^{6}$ Pada tahun 2010,jumlah bank syariah telah mencapai 11 dengan sekitar 1388 kantor BUS dan UUS di seluruh negeri.

Sejalan dengan perkembangan lembaga keuangan Islam yang disebutkan di atas, ulama diharapkan dapat memberikan kontribusi bagi perbaikan lembaga tersebut. Dalam rangka memenuhi tanggung jawab, Majelis Ulama Indonesia (MUI) membentuk Dewan Syariah Nasional (DSN) yang dianggap sebagai langkah efisien untuk mengelola pendapat hukum ulama ketika menanggapi isu-isu yang berkaitan dengan masalah keuangan dan ekonomi. Selain itu, DSN diharapkan dapat berfungsi sebagai advokat dari pelaksanaan ajaran Islam dalam kehidupan ekonomi. Untuk memahami infrastruktur industri perbankan syariah di Indonesia dapat dilihat dari gambar di bawah ini. ${ }^{7}$

Praktisi perbankan syariah membutuhkan fatwa DSN MUI sebagai pedoman dalam mengelola setiap praktek dan produk dari lembaga keuangan Islam. Pertumbuhan lembaga keuangan Islam harus didukung oleh fatwa hukum Islam yang valid dan akurat sehingga produk akan memiliki dasar hukum yang kuat. Oleh karena itu,MUI memprakarsai pembentukan Dewan Syariah Nasional (DSN). ${ }^{8}$

5 Lihat Muhammad Nadratuzzaman, 2013, Islamic Finance Product In Indonesia And Malaysia, Jakarta, Gramedia, hlm. 19-20.

6 Siti Faridah Abdul Jabbar, "the islamic financial services industry : the sharia boards goernance framework" (2013) 34 (10) company lawyer 297-301.

7 Lihat Muhammad Nadratuzzaman, 2013, Islamic Finance Product In Indonesia And Malaysia, Jakarta, Gramedia, hlm. 98.

8 Lihat Muhammad Nadratuzzaman, 2013, Islamic Finance Product In Indonesia And Malaysia, Jakarta, Gramedia, hlm. 98-99. 
DSN ini didirikanpada tahun 1999 dan berdirinya direkomendasikan dalam Lokakarya Nasional Islam Reksa Dana dilaksanakan pada bulan Juli 1997. Pendirian DSN itu didasarkan pada Keputusan MUI No. Kp. 754/MUI/II/1999 yang ditandatangai oleh Ketua Umum dan Sekretaris MUI. ${ }^{9}$ MUI kemudian mendirikan DSN sebagai sub bagian yang bekerja secara otonomdi bawah MUI, secara hierarkis dipimpin oleh Ketua Umum MUI. Kegiatan DSN dijalankan oleh kepalaDSN, sekretaris, dan beberapa anggota.

DSN sepenuhnya bertanggungjawab atas pengeluaran fatwa ${ }^{10}$ yang berkaitan dengan ekonomi Islam. Tujuan dari setiap fatwa sebagian besar diatur oleh DSN untuk memastikan bahwa setiap produk dan operasi bank syariah masih sesuai dengan hukum Islam. DSN mengeluarkan kebijakan sentralistik bertujuan untuk memastikan bahwa fatwa yang dikeluarkan sesuai dengan hukum islam. DSN bekerjasama dengan lembaga jeuangan Islam yang terkait, seperti Dewan Standar Akuntansi Keuangan, Ikatan Akuntan Indonesia, dan Biro Syariah dari Bank Indonesia.

Dalam rangka memberikan mekanisme pengawasan secara menyeluruh terhadap setiap lembaga keuangan syariah, maka Dewan Pengawas Syariah (DPS) didirikan. DPS terdiri dari orang-orang yang mengawasi dan meninjau produk dan layanan perbankan syariah agar kompatibilitas dengan prinsip-prinsip Islam. Produk yang sesuai dengan prinsip-prinsip tersebut mendapatkan label 'Islam', yang penting untuk penyerapan para investor muslim. DPS adalah kewenangan yang diberikan untuk mengawasi dan mengamati kegiatan lembaga keuangan Islam dalam rangka untuk memastikan bahwa lembaga-lembaga yang benar mematuhi prinsip-prinsip Islam dengan ketat. ${ }^{11}$

Dari penjelasan diatas, bahwa fatwa DSN-MUI menjadai pedoman bagipelaksanaan kegiatan perekonomian Islam bagi pemerintah dan bank-bankIslam. Fatwa DSN mengikat karena mereka diakui dalam Undang-undang yang sah. Selain itu, hubungan antara DPS dan DSN menjadi lebih kuat karena pengangkatan anggota DPS didasarkan pada rekomendasi dari DSN. Mereka juga terhubung satu sama lain ketika melakukan pengawasan, DPS harus mengacu pada fatwa yang dikeluarkan oleh DSN.

DPS umumnya merupakan bagian integral dari lembaga keuangan Islam yang secara langsung bertanggung jawab untuk mengamati operasi lembaga keuangan syariah sehingga operasi bank syariah selalu sesuai dengan Syariah, yang berari tidak melanggar fatwa dari DSN-MUI. ${ }^{12}$ Secara umum, DPS akan memeriksa aspek administrasi dan manajemen yang harus sesuai dengan hukum Islam. Yang paling penting, DPS menyetujui dan mengawasi produk-produk perbankan syariah yang sesuai denga hukum Islam dan perauran yang berlaku lainnya. Salah satu perbedaan struktural mendasar antara bank konvensional dan Bank Islam adalah selain operasi mereka diawasi oleh dewan komisi, bank syariah juga wajib diawasi oleh DPS agar sesuai dengan syariah. Pengawasan seperti itu tidak diperlukan bagi bank konvensional, bank konvensional hanya diawasi oleh dewan komisi. DPS terdiri dari ekonom dan ulama yang memiliki pengetahuan tentang hukum komersial Islam merupakanbadan independen yang bekerja untuk mengamati dan mengawasi operasional bank syariah dan produk mereka. DPS harus teliti dalam meneliti segala bentuk perjanjian, pengangkatan dan keterlibatan yang diakukan oleh lembaga keuangan Islam.

9 Mulya E. Siregar, 2007, Buildng an effective legal and regulatory framework for islamic banking : an indonesia case,

10 Fatwa merupakan pendapat maupun keputusan agamma yang dikeluarkan oleh para Ulama. Semua fatwa MUI, Himpunan fatwa MUI, Himpunan Fatwa Dewan Syariah Nasional MUI.

11 Muhammad Firdaus NH, 2005, buku ringkasan edukasi profesional sistem syariah dan mekanisme pengawasan syariah, renaisan, jakarta hlm. 16.

12 Dewi Nurul Mustjari, 2012, penyelesaian sengketa dalam praktik perbankan syariah, yogjakarta, parama publishing, hlm. 17. 
Dalam melaksanakan tugas mereka, DPS bertanggungjawab untuk (a) memberikan pengawasan berkala di Lembaga Keuangan Islam (b) mengusulkan aspek potensi untuk mempromosikan pengembangan Lembaga Keuangan Islam kepada pemimpin perbankan dan DSN (c) setidaknya dua kali setahun (d) mengidentifikasi masalah yang timbul dalam lembaga keuangan Islam yang akan dibahas dan diselesaikan melalui rekomendasi dari DSN. ${ }^{13}$

Menurut buku panduan yang diterbitkan oleh BI, DPS memiliki tiga posisi : (1) DPS bertindak sebagai penasihat dewan direksi dari unit perbankan syariah dan kantor cabang. (2) DPS bertindak sebagai mediator bagi bank syariah dan DSN, terutama jika menghubungkan usulan dan saran mengenai perkembangan produk dan jasa yang perlu penjelasan lebih lanjut dan fatwa dari DSN perbankan. (3) DPS bertindak sebagai wakil dari DSN dan DPS harus melaporkan kepada DSN tentang kegiatan usaha bank syariah dan perkembangan mereka. Laporan tersebut harus dibuat setidaknya sekali setahun. Kehadiran DPS juga menyarankan bahwa bank di bawah pengawasan mereka sesuai dengan hukum dan prinsip-prinsip Islam.

DPS terdiri setidaknya tiga orang yang diperbolehkan untuk memilih beberapa ekonom untuk membantu menjalankan tugasnya. Pembubaran atau penggantian anggota DPS harus direkomendasikan oleh dewan direksi dan disetujui oleh pemegang saham dalam Rapat Umum Pemegang saham (RUPS). Persyaratan yang harus dipenuhi oleh anggota DPS ditetapkan oleh DSN. ${ }^{14}$

Pengawasan yang efektif dalam perbankan sangat diperlukan dan dibutuhkan dalam perbankan Islam seperti halnya di bank konvensional. Untuk membantu mencapai tujuan ini sejumlah standar dan praktik terbaik didirikan dalam pengawasan perbankan agar beguna dan memberikan referensi yang berharga. Standar-standar ini, bagaimanapun, tidak selalu berlaku untuk perbankan syariah. Sebuah kerangka peraturan yang tepat dapat mengatur kebutuhan syariah dan menempatkan penekanan lebih esar dari manajemen risiko operasinal dan isu-isu keterbukaan informasi dari yang biasanya terjadi di perbankan konvensional. Untuk membantu mengembangkan kerangka peraturan seperti itu, sistem penilaian CAMELS diadopsi dari lingkungan Islam. ${ }^{15}$

Sistem CAMELS telah diperkenalkan untuk menilai tingkat kesehatan operasional bank syariah. Alat ini harus mengakomodasi fitur yang menonjol dari bank syariah, sehingga mamu digunakan sebagai alat pengawasan yang efekti tidak hanya untuk menilai kualitas operasional tetapi juga mengarahkan otoritas perbankan syariah saat merumuskan tindakan pengawasan berdasarkan penelaahan pengawasan. Pada dasarnya, alat yang dirancang masih dapat menggunakan sistem penilaian CAMELS tetapi dengan beberapa penyesuaian pada resiko keuangan dan penilaian manajerial. Secara umum, perbankan syariah bisa menggunakan sistem CAMELS ketika menilai tingkat kekuatan bank syariah. ${ }^{16}$

Sistem penialaian tingkat kekuatan bank syariah diharapkan dapat memberikan manfaat dalam proses pengawasan karena bisa mencerminkan kekuatan operasional yang objektif. Sistem rating kemudian akan digunakan sebagai dasar untuk merumuskan tindakan pengawasan. Oleh karena itu, dengan merancang sistem rating harus dapat menemukan masalah yang terjadi di Bank lebih tepat. Sistem penilaian tingkat kekuatan bank telah menjadi salah satu alat penting bagi otoritas perbankan untuk minilai kualitas operasional lembaga perbankan.

13 Heri Sunandar, "peran dan fungsi badan pengawas syariah dalam perbankan syariah di indonesia" (2005) 4 islamic law 159.

14 Lihat Muhammad Nadratuzzaman, 2013, Islamic Finance Product In Indonesia And Malaysia, Jakarta, Gramedia, hlm. 134-136.

15 Lihat Muhammad Nadratuzzaman, 2013, Islamic Finance Product In Indonesia And Malaysia, Jakarta, Gramedia, hlm. 135.

16 Lihat Muhammad Nadratuzzaman, 2013, Islamic Finance Product In Indonesia And Malaysia, Jakarta, Gramedia, hlm. 147. 
Sebuah bank dengan rating kualitas tinggi diharapkan dapat beroperasi secara berkelanjutan di masa depan. Setiap negara mungkin memiliki pendekatan yang berbeda ketika melakukan penilaian, tergantung pada kekhasannya. Sebagian besar negara menggunakan C(capital), A (aset), M (manajemen), E (earning), L (liquidity), dan S (Sensitivity to market risk) karena sistem rating sebagai kerangka kerja dalam melakukan kegiatan pengawasan. Mayoritas berbagai negara menggunakan CAMELS saat melakukan penilaian kualitas operasional perbankan. ${ }^{17}$

Desain regulasi perbankan syariah, harus dapat memperoleh manfaat dari perkembangan yang saat ini dicapai dalam sistem perbankan konvensional. Kerangka terbaru dari sistem CAMELS telah ditingkatkan untuk menggambarkan kesehatan struktural dari bank yang telah disesuaikan dengan penilaian resiko. Pendekatan ini akan sejalan dengan pelaksanaan Pengawasan Berbasis Resiko (RBS) sebagai pendekatan baru terhadap kegiatan pengawasan perbankan yang lebih efektif.

Bank Indonesia menerapkan CAMELS sebagai pengukuran kinerja bank syariah. Kinerja yang baik atau buruk dari bank sangat tergantung pada instrumen. Hal ini dirancang khusus untuk bank konvensional dengan sedikit penyesuaian untuk dapat diterapkan di bank syariah. ${ }^{18}$

\section{Peran Dan Posisi Fatwa Untuk Pengembangan Perbankan Syariah}

Posisi fatwa sangat signifikan dalam perkembangan ekonomi Islam Indonesia. Susunan fatwa ditelusuri kembali ke awal berdirinya perbankan syariah di Indonesia, ketika hukum dan kerangka peraturan untuk mendukung industri tidak cukup, itu adalah waktu dimana fatwa tersebut sangat diperlukan. ${ }^{19}$ Sampai saat ini, DSN telah mengeluarkan sekitar 73 fatwa pada pedoman kegiatan ekonomi Islam. Fatwa ini sangat penting untuk menanggapi keragaman peraturan dan memiliki peraturan pada beberapa hal.

Fatwa yag dikeluarkan oleh DSN-MUI mengikat secara hukum karena keberadaan mereka disahkan oleh Peraturan Bank Indonesia (PBI) sehingga para praktisi ekonomi Islam harus mematuhi fatwa tersebut. ${ }^{20}$ Di Indonesia, PBI setara dengan peraturan yang dikeluarkan oleh menteri dan peraturan ini memiliki kekuatan yang mengikat.

Setiap lembaga keuangan Islam wajib memiliki DPS karena tubuh ini merupakan wakil dari DSN. Badan ini mengakomodasi praktisi ekonomi Islam yang membutuhkan kepastian pada produk dan operasi dari sebuah bank Islam. Dalam hal ini, fatwa dapat dapat digunakan sebagai pedoman. Dalam peraturan fatwa, sumber pertimbangan utama adalah Qur'an dan Hadist. Kedua sumber utama hukum Islam tersebut selalu disebutkan dalam setiap pertimbangan hukum dari fatwa yang dikeluarkan oleh DSN.

Fatwa DSN-MUI dalam bidang ekonomi Islam, disusun dalam Kompilasi Hukum Ekonomi Islam (KHES). Fatwa DSN telah membuktikan bahwa sekitar 98 artikel dari KHES mirip atau bisa disebut berasal dari fatwa DSN. Hal ini menyimpulkan bahwa KHES adalah kompilasi dari hukum yang terdiri dari fatwa DSN. Fatwa ini menyimpulkan bahwa fatwa mwngikat secara hukum. ${ }^{21}$

17 Dadang Muljawan, “desain dalam sistem penilaian perbankan syariah : sebuah pendekatan terpadu” 309-344.

18 Endang sumachdar and hariandy hasby, 2011, “Analisis Pelaksanaan Pembiayaan Dalam Bank Perkreditan Rakyat Syariah Terhadap Modal Pihak Ketiga Dan Perbandingan Antara Bank Perkreditan Rakyat Konvensional Indonesia".

19 Hathout, Maher, "Demystifying the fatwah" the instituteof Islamic Indonesia and education.

20 Ahmad Hidayat Buang PhD and M. Cholil Nafis PhD "sharia banking laws and fatwa (Islamic legal resolution) in Indonesia” (2003) 28 (12) journal of International banking law and regulation 471-478.

21 Halim, Shah Abdul, "Islam \&Pluralism : A contemporary approach" 
Sebuah fatwa daat bertindak sebagai sebuah institusi dalam hukum Islam karena menyediakan jawaban dan solusi untuk masalah-masalah yang dihadapi oleh agama Islam. ${ }^{22}$ Bahkan, umat Islam pada umumnya mengacu pada fatwa dan adanya fatwa pasti penting bagi perkembangan perbankan syariah di Indonesia. Penegasan ini wajar karena pada awal perbankan syariah, secara hukum tidak dapat support peraturan yang memadai dari pemerintah. Pada saat itu masih kekurangan hukum dan kerangka regulasi karena itu fatwa dari DSN memiliki peran yang sangat penting.

Fenomena tentang ekonomi Islam memiliki bentuk perkembangan yang resmi dan bahkan modernisasi fiqh muamalah Maliyah. ${ }^{23}$ Umumnya, fatwa merupakan penjelasan-penjelasan hukum-hukum yang terdiri dari pedoman untuk lembaga keuangan. Penafsiran seperti itu sangat dibutuhkan oleh praktisi ekonomi Islam. Dalam hal ini, DSN akan memberikan bimbingan dan oenjelasan kepada orang-orang pada norma ekonomi Islam.

Dalam studi ilmu fiqh klasik, fatwa hanya mengikat bagi mereka yang meminta fatwa dan mengeluarkan fatwa. ${ }^{24}$ Namun, konsep fatwa ini kemudian diganti dan diperbarui, saat ini fatwa DSN pada ekonomi Islam tidak hanya mengikat bagi praktisi ekonomi dan DSN personil Islam tetapi juga umat Islam di Indonesia yang bertransaksi dengan menggunakan Bank Syariah. Selain itu, fatwa ini telah disahkan oleh Peraturan Bank Indonesia.

Fatwa DSN saat ini telah melalui beberapa proses dan rumus kelembagaan, koneksi, dan fatwa kolektif yang ijtihad jama'iy (ijtihad kolektif) dalam perekonomian Islam. ${ }^{25}$ Atas dasar ini, kepastian dan posisi fatwa DSN yang legal hampir seperti ijma' (konsensus). Kewenangan mengeluarkan fatwa dalam perekonomian Islam Indonesia terletak di bawah DSN - MUI. Para anggota dewan dari DSN adalah ahli dalam hukum Islam dan keuangan Islam.

Definisi klasik fatwa telah berkembang dan memperkuat posisi fatwa kentemporer yang institusional dan kolektif. Fatwa yang dikeluarkan oleh Komisi Fatwa MUI menjadi rujukan bagi masyarakat dan mengikat umat Islam di indonesia. ${ }^{26}$ Fatwa DSN, bagaimanapun, menjadi rujukan mengikat bagi lembaga keuangan Islam di negara ini dan mereka juga mengikat orang-orang yang meakukan transaksi dengan lembaga keuangan Islam.

\section{Produk Perbankan Syariah}

Minat masyarakat dalam perbankan Islam direspon secara positif oleh banyak bank yang menawarkan layanan perbankan syariah baru melalui konversi dan metode spin-off. Bank konvensional diperoleh dan diubah menjadi bank umum syariah atau divisi perbankan syariah (UUS) yang mengalami spin-off dan berubah menjadi Bank Umum Syariah (BUS). Tercatat lima bank umum Islam yang baru didirikan pada tahun 2010, baik yang melalui konversi atau spin-off. Penambahan lima BUS baru ini merupakan penambahan tertinggi yang pernah tercatat dalam sejarah perbankan syariah Indonesia. Hal ini mengakibatkan persaingan yang tinggi dalam perbankan Islam. Hal ini pentig untuk dikatakan bahwa peningkatan yang luar biasa dalam industri perbankan syariah dapat dipertahankan.

Pelaksanaan dalam operasional bank syariah tidak sama dengan bank konvensional. Bank konvensional tidak mungkin untuk menghapuskan peran bunga dalam operasi mereka.

22 Halim, Shah Abdul, "Islam \& Pluralism : A contemporary approach"

23 Yeni Salma Barlinti, peran dan fungsi fatwa dari dewan syariah nasional MUI dalam sistem hukum di Indonesia (badan litbang dan diklat, kementerian agama RI 2010) 98.

24 Samy Nathan Garas and Chris Pierce, "sharia a supervision of Islamic financial institutions" 201018 JFR 386400.

25 Ali Abdulrahim Ali, "the role of Islamic jurisprudence in finance and development in the muslim world" (2010) 31 Comp Law 121-127.

26 Fakihah Azahari Advocate \& Solicitor of the igh Court of malaya shariacounsel, "Islamic finance sharia principles of transformation and assimilation" (2007) 74 (1) The maaya law jurnal articles 63-78. 
Bunga merupakan hal yang paling utama dalam operasional bank konvensional. Yang mana merupakan alat untuk pencairan dana. Serta mendorong orang untuk menabung dana mereka. ${ }^{27}$ Selain itu, bunga adalah sumber pemasukan bank, yang memotivasi orang untuk berinvestasi dalam peluang bisnis. Perubahan suku bunga memicu komentar pada setiap sisi ekonomi. Bank dapat memberikan berbagai komentar pada kenaikan atau penurunan suku bungan yang dikeluarkan oleh bank sentral.

Secara umum, bank bertujuan untuk mempromosikan dan mempercepat perkembangan ekonomi suatu masyarakat tertentu melalui kegiatan keuangan yang sesuai dengan prinsip syariah dan perbankan. Usaha tersebut harus didasarkan pada larangan pengisian bunga pada setiap transaksi dan kemitraan prinsippada setiap kegiatan usaha, yang harus didasarkan pada larangan pengisian bunga pada setiap transaksi dan kemitraan prinsip pada setiap kegiatan usaha, yang harus didasarkan pada dasar kesetaraan, keadilan, dan tidak hanya bertujuan untuk sekedar memperoleh keuntungan tetapi juga untuk mencapai ketenangan dalam akhirat melalui pembayaran zakat dan sedekah.

Pada mulanya, inisiatif untuk mendirikan bank tanpa menerapkan sistem berbasis bunga hanya ada dalam wacana teoritis ekonom Islam. Pemikiran seperti itu akhirnya membuat orang-orang sadar bahwa bank Islam bisa menjadi salah satu solusi untuk memecahkan masalah-masalah ekonomi dan sosial kesejahteraan. Ia kemudian mencoba konsep perbankan tanpa bunga akan dimasukkan ke dalam praktek. ${ }^{28}$

Secara umum, semua transaksi yang terjadi dalam perbankansyariah pada dasarnya sama dengan bank konvensional. Namun, sistem ekonomi Islam menekankan konsep manfaat bagi kegiatan ekonomi yang lebih luas di setiap transaksi. Setiap kegiatan transaksi harus mengikuti konsep manfaat dan harus menjunjung tinggi prinsip-prinsip keadilan. Karena bank syariah didasarkan pada prinsip-prinsip kemitraan, keadilan, transparansi, universitas atau ajaran Islam, sistem operasional dapat dibagi menjadi tiga kategori utama $:^{29}$

a. Pembiayaan produk, yang mana bertujuan untuk membiayai kebutuhan masyarakat/ menyalurkan dana ke masyarakat

b. Pendanaan produk, yang mana bertujuan untuk mengumpulkan dana dari masyarakat. Perbedaannya ada pada Landasan Falsafahnya, jika Bank Konvensional berlandaskan filosofi bunga dalam setiap transaksinya, sementara bank syariah menggunakan dasar falsafahnya bagi hasil untuk setiap kegiatan operasionalnya.

c. Layanan jasa, yang mana bertujuan untuk melayani kebutuhan masyarakat akan jasa pelayanan di bank syariah.

Pendanaan berarti bahwa kegiatan bisnis yang dilakukan oleh bank untukmengumpulkan dana dari penabung, dana yang terkumpul nantinya akan disalurkan kepada peminjam. Dalam hal ini, bank bertindak sebagai perantara antara penabung dan peminjam. ${ }^{30}$ Dalam kasus bank syariah, klasifikasi dana - pertemuan utama tidak didasarkan pada nama produk, melainkan pada prinsip-prinsip yang digunakan. Menurut fatwa Dewan Syariah Nasional, ada dua prinsip pengumpulan dana yang digunakan dalam bank syariah, yairu wadiah dan mudharabah. ${ }^{31}$

27 Kodifikasi produk perbankan syariah, pimpinan codification of Islamic banking products, pimpinan bank syariah Indonesia.

28 Shameela Chinoy, "Interest- free banking : the legal aspects of Islamic financial transactions" (1995) 10 (12) J.I.B.L, $517-524$.

29 Green v Alexander Johnson, "Case Report" (2006) 22 (5) Const. L.J. 336 -343.

30 Hans Visser, Islamic Finance : principles (2nd ed, Edward Elgar Publishing 2013) 52.

31 Mudharabah merupakan perjanjian antara dua orang atau lebih dimana investor (rabbul maal) mempercayakan uangnya kepada agen manager (mudarib) untuk berdagang dan mengembalikan uang kepada investor atas prinsip bagi hasil dan rugi. 
Kewajiban Bank yaitu menyimpan tabungan masyarakat atau mengumpulkan uang dari pihak ketiga. Dalam sistem perbankan konvensional, tabungan merupakan sumber dana yang paling dominan. Bank juga melakukan kegiatan peminjaman antar bank, serta dengan menerapkan kewajiban kepada investor. Penghematan yang diterima oleh bank harus didukung oleh presentase tertentu yang disediakan sebagai cadangan likuiditas. Dalam kasus sistem perbankan Islam, di sisi lain, tabungan berdasarkan prinsip wadiah dan mudharabah. ${ }^{32}$

Selain itu, jika sebua bank Islam memiliki kurang atau lebih banyak likuiditas dalam operasinya, bank bisa mendapatkan bantuan likuiditas dari Pasar UangAntar bank Syariah (PUAS). Bank-bank Islam mungkin mengalami kekurangan likuiditas yang disebabkan oleh perbedaan waktu antara penerimaan dan investasi dana atau akses likuiditas yang bisa terjadi karena dana yang terkumpul tidak bisa didistribusikan kepada mereka yang membutuhkan. Dalam rangka meningkatkan efisiensi pengelolaan dana, bank melakukan kegiatan usaha berdasarkan prinsip syariah memerlukan Pasar Uang Antar bank Syariah(PUAS). ${ }^{33}$ Faktanya bank dengan kelebihan likuiditas akan menginvestasikan dana mereka di bank-bank yang mengalami problem likuiditas. Kontrak yang biasanya digunakan yaitu mudarabah , didirikan antara pemilik dana oleh manajer investasi, dimana mereka setuju untuk bebagi hasil dengan rasio atau persentase tertentu. Meskipun praktik pasar uang ini ada, namun volumenya kecil, dalam kenyataannya, pembiayaan bank syariah relatif mampu menyerap dana pihak ketiga yang ada. FDR (Financing to Deposit Ratio) menafsir sekitar 90\% terbukti sah dalam hal ini. Tidak seperti kegiatan pasar uang konvensional, kegiatan dalam PUAS tidak terlalu aktif karena pengelolaan likuiditas didalamnya menjadi sangat kuat. Hal ini sangat jarang untuk sebuah bank Islam yang memerlukan likuisitas dari sumber-sumber luar PUAS. Alasan lain untuk fakta bahwa PUAS tidak terlalu aktif yaitu bank syariah berkonsentrasi pada pembiayaan sektor riil. Bank-bank tidak mndapatkan keuntungan dari jual beli surat berharga di pasar keuangan syariah.

Pasar Uang Antarbank Syariah (PUAS) pada dasarnya dimaksudkan sebagai investasi pada Bank Islam sehingga bank syariah tidak bisa berinvestasi di bank konvensional untuk menghindari penggunaan dana yang mengandung prinsip-prinsip yang dilarang dalam Islam, seperti bunga, unsur gharar, dan maysir. Namun, PUAS juga memungkinkan bagi bank konvesional untuk berinvstasi di perbankan syariah. Mengenai dua instrumen tersebut tampaknya menjadi alternatif dari operasi perbankan yang mnggunakan prinsip-prinsip Islam untuk menangani likuiditas.

Pasar Uang Antar Bank digunakan sebagai investasi dan transaksi, seperti dalam pengelolaan perbankan. Faktanya, yang menyimpan dan menarik dana tidak dapat diprediksi, tetapi dapat dihitung sesuai dengan masa investasi. Di sinilah manajemen harus secara simultan mempertimbangkan berbagai resiko yang akan mempengaruhi perubahan dana. Fasilitas pasar uang antar bank merupakan sarana untuk mengatasi masalah ini, terkait dengan operasi perbankan Islam dikenal sebagai Pasar Uang Antarbank Syariah (PUAS) adalah investasi jangka pendek dalam mata uang Rupiah Indonesia antara pelaku pasar berdasarkan prinsip Mudharabah, dimana transaksi menggunakan sertifikat Investasi Mudharabah Interbank (sertifikat IMA) adalah sertifikat digunakan untuk mendapatkan dana dengan prinsip mudharabah.

Adapun bank syariah yang memiliki kelebihan likuiditas, di samping menyalurkan langsung ke sektor riil, bank juga dapat membeli sukuk (Obligasi syariah), meskipun sukuk tepi juga menyalur ke sektor riil. Selain itu, bank syariah juga membeli dapat membeli SBIS (Sertifikat Bank Indonesia Syariah).

32 A.L.M Abdul Gafoor, Interest Free Commercial Banking (A.S NOORDEEN 2010) 37.

33 Tim Lindsey, 'Between piety and prudence : state syariah and the regulation of islamic banking in indonesia' (2012) 34 Sydney L. Rev. 107. 
SBIS terhubung dengan sistem perbankan, sebagai instrumen pengendalian moneter dengan memantau kinerja bank umum, bank syariah juga masuk ke dalam kategori bank untuk melakukan transaksi dengan bank sentral dalam hal ini. Karena perbankan syariah umumnya berusaha untuk menghindari sebanyak mungkin unsur maysir, gharar, riba yang menggunakan sertifikat Bank Indonesia (SBI) sistem berdasarkan pada tingkat suku bunga, maka muncullah apa yang disebut Sertifikat Bank Indonesia (SBI) .

\section{KESIMPULAN}

Keberhasilan perbankan syariah di masa depan tergantung pada kemampuan bank syariah untuk menyajikan produk-produk yang menarik dan kompetitif yang diakui mampu memberikan transaksi yang lebih mudah untuk memenuhi permintaann pelanggan.Seperti disebutkan sebelumnya, menurut survey yang dilakukan oleh BI dan beberapa perguruan tinggi, masyarakat Indonesia sebenarnya mendukung gagasan pendirian bank Islam. Dukungan tersebut tergantung pada dasar rasional yang berarti bahwa orang-orang akan mendukung bank-bank Islam jika mereka mampu bersaing dengan bank-bank konvensional dan menawarkan produk-produk inovatif.

Inovasi produk harus menjadi prioritas strategis bank syariah karena inovasi memainkan peran penting dalam pasar yang kompetitif. Maka dari itu, industri perbankan syariah harus terus melakukan inovasi-inovasi baru. Produk yang sudah ada bank syariah cenderung lebih statis karena mereka hanya terbatas pada tabungan, deposito, giro, mudharabah, murabahah, dan musyarakah, Pada akhirnya jumlah produk ini masih terbatas.

Dengan demikian, bank-bank Islam harus mengembangkan produk yang bervariasi dan mengkombinasikannya, sehingga bank akan lebih menarik. Hal ini dianggap akan membantu untuk meningkatkan kebutuhan perbankan syariah dalam hal pemenuhan kompleks orang-orang modern. Yang penting, bank harus mengalokasikan dana untuk mengembangkan kualitas sumber daya melalui pelatihan atau lokakarya tentang produk-produk inovatif. Bank-bank juga harus memperimbangkan untuk memberikan beasiswa bagi karyawan mereka untuk mengambil gelar sarjana di bidang ekonomi Islam.

\section{DAFTAR PUSTAKA}

A.L.M Abdul Gafoor, Interest Free Commercial Banking (A.S Noordeen 2010) $37 \backslash$

Ahmad Hidayat Buang Phd And M. Cholil Nafis Phd. Sharia Banking Laws And Fatwa (Islamic Legal Resolution) In Indonesia. (2003) 28 (12) Journal Of International Banking Law And Regulation 471-478.

Ali Abdulrahim Ali, The Role Of Islamic Jurisprudence In Finance And Development In The Muslim World, (2010) 31 Comp Law 121-127.

Dadang Muljawan, Desain Dalam Sistem Penilaian Perbankan Syariah : Sebuah Pendekatan Terpadu, 309-344

Dewi Nurul Mustjari, 2012, Penyelesaian Sengketa Dalam Praktik Perbankan Syariah, Yogjakarta, Parama Publishing

Endang Sumachdar And Hariandy Hasby, 2011, Analisis Pelaksanaan Pembiayaan Dalam Bank Perkreditan Rakyat Syariah Terhadap Modal Pihak Ketiga Dan Perbandingan Antara Bank Perkreditan Rakyat Konvensional Indonesia

Fakihah Azahari Advocate \& Solicitor Of The Igh Court Of Malaya Shariacounsel, Islamic Finance Sharia Principles Of Transformation And Assimilation, (2007) 74 (1) The Maaya Law Jurnal Articles 63-78.

Fathurahman Djamil, 2002, Urgensi Undang-Undang Perbankan Syariah Di Indonesia, Jurnal 
Hukum Bisnis.

Fatwa Merupakan Pendapat Maupun Keputusan Agamma Yang Dikeluarkan Oleh Para Ulama. Semua Fatwa Mui, Himpunan Fatwa MUI, Himpunan Fatwa Dewan Syariah Nasional Mui.

Gemala Dewi, 2006, Aspek-Aspek Hukum Dalam Perbankan Dan Peransurasian Syariah Di Indonesia, Jakarta, Prenada Media.

Green V Alexander Johnson, Case Report, (2006) 22 (5) Const. L.J. 336 -343.

Halim, Shah Abdul, Islam \& Pluralism : A Contemporary Approach

Hans Visser, Islamic Finance : Principles (2nd Ed, Edward Elgar Publishing 2013) 52.

Hathout, Maher, Demystifying The Fatwah” The Instituteof Islamic Indonesia And Education

Heri Sunandar, Peran Dan Fungsi Badan Pengawas Syariah Dalam Perbankan Syariah Di Indonesia (2005) 4 Islamic Law 159.

Kodifikasi Produk Perbankan Syariah, Pimpinan Codification Of Islamic Banking Products, Pimpinan Bank Syariah Indonesia

Muhammad Nadratuzzaman, 2013, Islamic Finance Product In Indonesia And Malaysia, Jakarta, Gramedia

Muhammad Firdaus Nh, 2005, Buku Ringkasan Edukasi Profesional Sistem Syariah Dan Mekanisme Pengawasan Syariah, Renaisan

Mulya E. Siregar, 2007, Buildng An Effective Legal And Regulatory Framework For Islamic Banking : An Indonesia Case

Samy Nathan Garas And Chris Pierce, Sharia A Supervision Of Islamic Financial Institutions, 201018 Jfr 386-400

Shameela Chinoy, Interest- Free Banking : The Legal Aspects Of Islamic Financial Transactions, (1995) 10 (12) J.I.B.L, 517 - 524.

Shanty Rachagan, Islamic Banking In Malaysia, (2005) 20 Jiblr 88-94

Siti Faridah Abdul Jabbar, Money Laundering Laws And Principles Of Sharia : Dancing To The Same Beat?, (2011) 14 Jmlc 198, 209.

Siti Faridah Abdul Jabbar, The Islamic Financial Services Industry: The Sharia Boards Goernance Framework (2013) 34 (10) Company Lawyer 297-301.

Siti Faridah Abdul Jabbar, The Islamic Financial Services Industry: The Sharia Boards Goernance Framework, (2013) 34 (10) Company Lawyer 297-301.

Sutan Remy Sjahdeini, 1993, Kebebasan Berkontrak Dan Perlindungan Yang Setimbang Bagi Para Pihak Dalam Perjanjian Kredit Bank Di Indonesia, Jakarta, Institut Bankir Indonesia.

Tim Lindsey, Between Piety And Prudence : State Syariah And The Regulation Of Islamic Banking In Indonesia, (2012) 34 Sydney L. Rev. 107.

Yeni Salma Barlinti, Peran Dan Fungsi Fatwa Dari Dewan Syariah Nasional Mui Dalam Sistem Hukum Di Indonesia, (Badan Litbang Dan Diklat, Kementerian Agama Ri 2010) 98. 